\title{
Work Value, Knowledge Sharing, and Creative Performance among Construction Employees in Jakarta
}

\author{
Bimmo Dwi Baskoro \\ Sekolah Tinggi Manajemen Labora, \\ No. 7-8, Jl. Palem Raja, Taman Modern, Jakarta, Indonesia, 13910 \\ bimmodibi@gmail.com
}

\begin{abstract}
This research aimed to indicate the effect of work values of construction employees towards creative performance and to assess the role of mediation about sharing the knowledge among those variables. This research involved 315 respondents from various construction companies in Jakarta for assessing hypothesis research. Knowledge sharing had the role as mediator among comfort and status dimensions from work values towards creative performance. This research provided information about effect of work values towards creative performance from construction industry and confirmed the role of knowledge sharing in mediating work values dimension.
\end{abstract}

Keywords: work values, creative performance, knowledge sharing

Conflicts of interest: The author declared no conflicts of interest.

Acknowledgements: The author thanks to Sekolah Tinggi Manajemen Labora, DKI Jakarta, Indonesia for supporting this research.

\section{Article history:}

The article was submitted on 20.01.2021. The article was accepted on 18.02.2021.

\section{For citation:}

Baskoro B.D. Work Value, Knowledge Sharing, and Creative Performance among Construction Employees in Jakarta. RUDN Journal of Public Administration. 2021; 8 (2): 200-215. DOI: $10.22363 / 2312-8313-2021-8-2-200-215$

\section{Introduction}

For several years, there are a bigger number of researches which have focused on employees' creative performance at work [1;2;3]. It is triggered by the evidence of creative performance as significant factors in determining sustainable living and company development [4;5]. The company innovation performance in Indonesia can be seen at project performance, marketing performance, company excellence, and competitive supremacy $[6 ; 7 ; 8]$. In China, the pressure of creative performance is extremely vital for companies since they 
struggle to create competitive excellence through the creative performance in market and number of products $[9 ; 10]$. The research conducted in public sector in Norway by Mutonyi et al. [11] obtains data that creative performance is influenced by organization climate.

Company creative performance is related to its employees and they play significant roles in creative performance [12]. The key to promoting company creative performance is increasing its creative performance [13; 14]. This research provides employees performance which has found many factors influencing employees creative performance such as psychological modal [15], knowledge sharing [16;17], creative climate [18], leadership style [19;20;21], employees involvement [22], gift [23], and psychological contract [24]. These factors can be classified into two major categories: behavior and psychology [24]. However, a bigger number of researchers have found that the factors are influenced by work values, and the researches have set work values as antecedent factor influencing employees behavior and psychology [25; 26]. Work values influence employees behavior and determine their performance $[27 ; 28 ; 29]$. Therefore, we propose that work values possibly have significant effects on employees' creative behavior and creative performance.

Knowledge sharing is defined as an activity which is involved in knowledge distribution and transfer among individual, group, or organization [30; 31]. It has positive effects to the organization as it can promote knowledge current, information and improve creative level of organization, and individual. [32; 33; 34; $35 ; 36]$. Indeed, knowledge sharing is supported by three major factors; there are individual organization, and information technology $[32 ; 37 ; 38]$, and people are the central factor. Hence, how to support behavior of knowledge sharing to employees is a significant research. Whereas, several researchers learn knowledge sharing from employees perspective [34; 39], the study of knowledge sharing mechanism from employee work values perspective, it rarely occurs and it needs to conduct relevant research.

Briefly, the research has found countless factors influencing creative performance, but few researches have focused on correlation between work values and creative performance, mainly from knowledge sharing perspective $[40 ; 12 ; 39]$. To complete this discrepancy, this research shows correlation of both subjects with empirical study, whereupon explores the effects of work values and knowledge sharing on creative performance.

\section{Literature Review and Hypothesis}

Work Values. The research in accordance with work values has been conducted for decades. Most of researches assume work values as major criteria when the employees are evaluated for their work [27; 41]. The research from various perspectives (e.g. demography) have explored the factors causing employees work values and found that age [42;43;44;45], sex [46; 27; 47], level of education [48], and personality [49] which are all significant. At the same time, many empirical studies have focused on the effects produced by work values [50; 
$51 ; 52 ; 53]$. They conclude that work values do not only influence employees psychology variables, for instance job satisfaction, [28] and commitment of organization [28; 54], but also they impact upon behavior variables, for example organization nationality behavior and to show work values are major factors influencing psychology and employees behavior.

In this research, work values are defined as employees' internal standard to evaluate factors related to job. Adopting a suggestion from Meyer et al. [54], we divide work values into three dimensions: comfort and security (Comfort), competence and growth (Competence) and status and independence (Status). Since employees in Indonesia are attractive, especially for perspective assessment to assess behavior and result of work, classification method stated by Meyer et al. [54] is suitable for study of employees in Indonesia.

Work values and creative performance. Based on self-verification theory [55], an individual keeps searching or triggering a consistent feedback with selfconcept to maintain his own view and proof it through result of work. This theory also shows an individual behavior and manner who is consistent, and this individual adopts the right behavior which they consider. Work values are an individual assessment towards his work behavior. The behavior and individual value assessment in a consistent work and they affect individual's behavior and result of work. This opinion is supported by result of researches which exist. That research has found the work values which influence employees' work behavior $[50 ; 56]$. Moreover, work values have significant effects on creative performance $[57 ; 58]$. Because creative performance is one of creative performance forms, this research hypothesizes that work values can influence creative performance. However, this research shows "work value" as a large term for various dimensions (comfort, competence, and status) and every dimension has different orientation of value evaluation [54]. According to self-verification theory, different orientation of value evaluation may produce the different performance. Therefore, it has different effects on creative performance.

First dimension, comfort, is mainly assessed as work security, workplace stability, office hour, and clarity of problem solving. The employees who have high convenience work values are more conservative. They do not accept challenge or try a new method or work idea and they will not locate longer time and bigger energy at work. Therefore, convenient work value is not conducive for creativity.

H1. Comfort will have negative correlation with creative performance.

Second dimension of work value, competence, related to learning, communication, work autonomy, creativity, and work achievement. These factors are considered as positive correlation with creative performance for being creative, employees need to have creative motive and they are involved in sustainable learning and communication. Therefore, we hypothesize that employees having higher competence work values will be more creative:

H2. Competence will have a positive correlation with creative performance. 
Third dimension of work values, status particularly refers to evaluation of income value, promotion, needs to independently work, and feel sense of honor. The employees who pursue status can be more paying attention to creative activity. Since success in creative performance can pay the employees who pursue status of making extra money and promotion. The inventive employee can earn higher respect from their director and colleague. It can be concluded that, the employees who pursue Status at work will bring better creative performance for their work:

H3. Status will have a positive correlation with creative performance.

Knowledge sharing and creative performance. Knowledge is a significant factor which influences creative performance, and efficiency of knowledge sharing influences employees creative performance level [16; 59; 17]. Knowledge sharing can create unrestricted knowledge current $[60 ; 31]$, it enables the employees to use full knowledge. [60;31], enhancing the use efficiency of organization natural resources [61], promoting creativity at once [62;63]. Related to empirical study shows that knowledge sharing can provide the chance for employees to obtain sufficient information [16] and it helps them to comprehend and accept new ideas. Thus, promoting creativity $[64 ; 17]$ :

H4. Knowledge sharing will have a positive correlation with creative performance.

Mediating roles of knowledge sharing. Values are kinds of faith [65], inspiring intrinsic individual motivation [66], and influencing result of work by altering their behavior [25]. Toode et al. [67] shows that work values influence employees' work behavior having their turn to impact quantity and quality of work which they produce. So, we assume that work values have indirect effects towards quality of work. Meanwhile, knowledge sharing can generate knowledge and latest information to employees, and it can help them to analyze problem from recent perspective, creating new methods and elevating their creativity level. Empirical study found that knowledge sharing can promote employee's creative performance as well [59].

On the other hand, knowledge sharing is kind of work behavior and it is influenced by intrinsic values [27]. We propose that employees work behavior will be influenced by work values at work. According to social exchange theory when employees need to obtain relevant knowledge and information for creative performance, they do not only obtain it from others, but they also actively share their knowledge and information. Therefore, knowledge sharing is conducted among employees. Accordingly, the employees work values will have an impact on their knowledge sharing behavior. Based on the analysis, this research proposes that the role of knowledge sharing could be a meditation between work values and creative performance:

H5. Knowledge sharing mediates the correlation between work values and creative performance. 


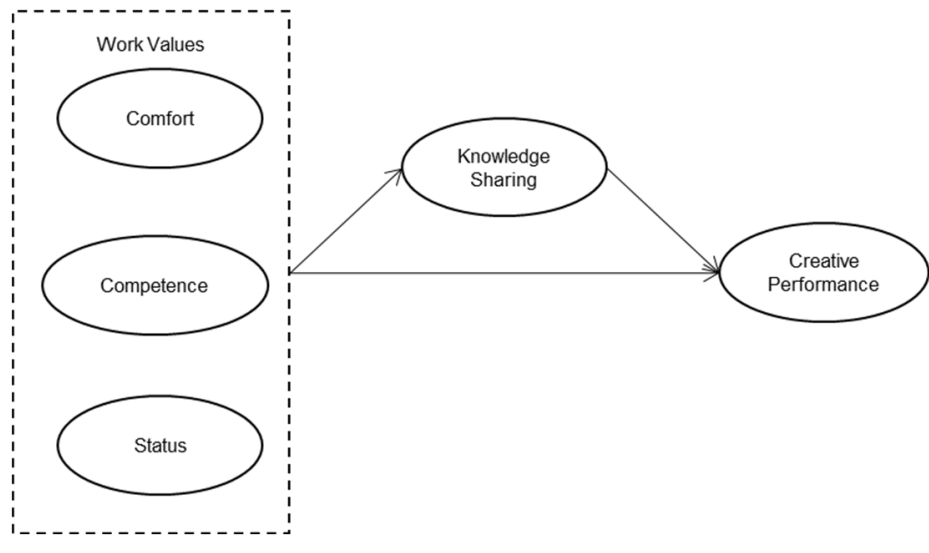

Fig. 1. Research model

Source: Researchers Own Survey (2020).

\section{Method}

Participants. The population of this research was 1.718 construction company representatives (with engineer as their minimum position) from 1.718 construction companies (private and public) affiliated with Jakarta branch of Gapensi (Indonesian Nasional Construction Board) as research target. The sample determination used Slovin formulation approach [68] at the precision level calculation of $5 \%$ and was obtained the sample of 324 construction company representatives who were involved in this research. We sent questionnaires to 324 construction company's representatives by email; from such amount, 315 respondents returned their questionnaire and delivered the response level of $97.22 \%$. $67(21.3 \%)$ respondents were female; $248(78.7 \%)$ were male. 3 people (1\%) had experience for $1-5$ years, 7 people $(2.2 \%)$ had experience for $6-10$ years, and 305 people (97.1\%) had experience for 11-15 years of work. In terms of educational background, 2 people $(0.6 \%)$ had diploma degrees, 312 people $(99 \%)$ had bachelor's degrees, and 1 person $(0.3 \%)$ had master's degree. In terms of occupational background, 2 people $(0.6 \%)$ worked as engineer, 3 people $(1 \%)$ worked as project management team, 306 people $(97.1 \%)$ worked as leader, and 4 people $(1.3 \%)$ as other staff.

\section{Variable measures}

Work values (WV). We measured work values by using 21-item scale developed by Meyer et al. [54] $(\alpha=0.820)$. This scale included 3 dimensions: comfort (CF), competence (CPT), and status (ST). Comfort dimension was measured with five-item scale (e.g. "Allowing daily routine within work time and place"). Competence dimension contained of seven-item scale (e.g. "Requiring meeting and communicating with many people"). Status dimension was measured with nine-item scale (e.g. "Advancing permission to a higher administration responsibility"). The values of $\alpha$ for these three types of scale were $0.872,0.903$, and 0.888 . These items were measured on five-value Likert type scale, started from 1 "not important" to 5 "very important". 
Knowledge-sharing intention (KS). We assessed participants' intention of knowledge sharing using 4-item scale developed by Pi et al. [69]. The item example was "I enjoy sharing knowledge and experience with my colleagues". The coefficient of $\alpha$ for this scale was 0.900 . These items were measured on the scale of 1 "strongly disagree" to 5 "strongly agree".

Creative performance (CP). Managers who were familiar with the employees' behavior were demanded to assess the creative performance of employees by using four-item scale [70]. The example was "Providing new ideas to improve the existing condition". The coefficient of $\alpha$ for this scale was 0.840 [71]. These items were measured on five-point scale of 1 "never happened" to 5 "frequently".

\section{Analysis}

The inferential statistical analysis was used to test the research hypothesis in accordance with Figure 1 was structural equation modeling - partial least squares (SEM-PLS) by using SmartPLS 3.2.8 software. The significance used in this research was 0.05 and was also used one-tailed test. The quantitative approach was used in data analysis. Besides, descriptive statistical analysis was used for determining the frequency distribution of filled answers and questionnaires.

\section{Result and discussion}

Measurement model. Evaluation of the measurement model (outer model) performed to determine the validity and reliability that connects the indicator with its latent variable. There are three criteria in using data analysis techniques with SmartPLS 3.2.8 to evaluate the outer model, namely, convergent validity, discriminant validity, composite reliability, and average variance extracted (AVE) $[72 ; 73]$.

Convergent validity of the measurement model with reflective indicators is evaluated based on the correlation between item scores/component scores estimated with PLS software. Individual reflective measures are said to be high if they correlate more than 0.70 with the construct measured [73]. In this research, a loading factor limit of 0.70 will be used. There is still an outer loading value below 0.70 . Because it has a low convergent validity value, statement items that have a loading factor below 0.70 must be removed (deleted). Two indicators on Competence must be removed i.e. Competence 2 and Competence4. In the Knowledge Sharing construct, one indicator must be removed i.e. KnowledgeSharing5. The results of data processing for loading values less than 0.70 that have been deleted are shown in Figure 2.

Discriminant validity analysis. After ensuring that all indicators of the latent variable are constructs of the latent variable, the next step is to test the discriminant validity. Discriminant validity also needs to be done so that the scale used does not comprise two constructs that measure the same thing. To find out, the correlation between constructs must be less than 0.90 . If between constructs, the correlation is 0.90 or more, multicollinearity between constructs will occur [73]. The results of discriminant validity testing are shown in Table 1. 
As shown in Table 1, there is no multicollinearity between variables because each construct measures different things. This is evident from the correlation value between constructs that is less than 0.90 .

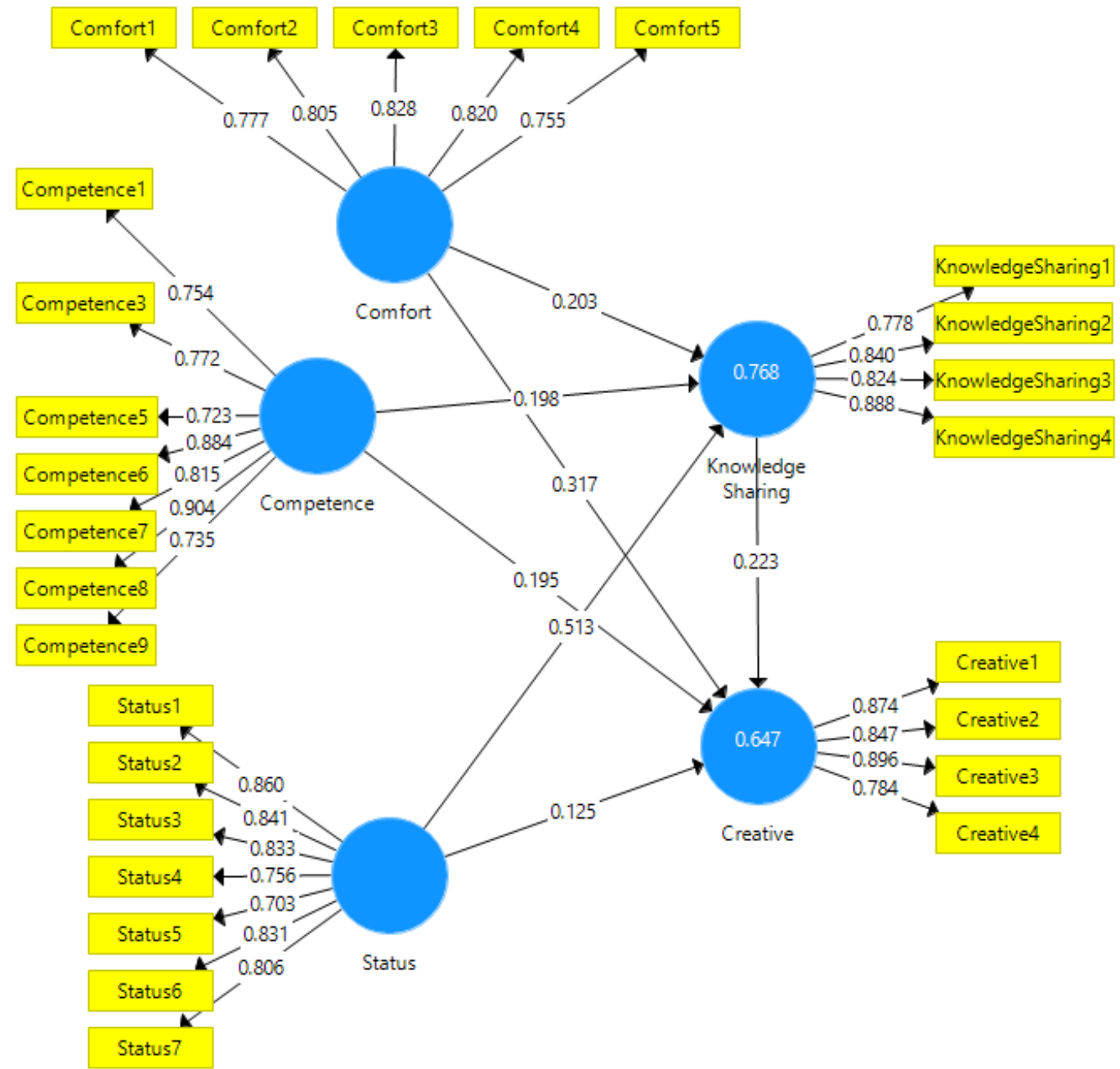

Fig. 2. Result of structural equation modelling Source: Researchers Own Survey (2020).

Reliability evaluation and AVE. The validity and reliability criteria can also be seen from the reliability value of a construct and the value of the AVE of each construct. The construct is said to have high reliability if the value is 0.70 and AVE is above 0.50 [73]. The composite reliability indices of each scale were all greater than the level of 0.70 recommended by Fornell \& Larcker [74]. Table 1 presents Cronbach's alpha, composite reliability (CR), and AVE values for all variables.

As shown in Table 1, CF, CPT, ST, KS, and CP have a composite reliability above 0.80 and a Cronbach's alpha value above 0.70 ; hence, it can be concluded that the indicators used in every variable has good reliability or can measure its construct [73]. However, the Cronbach's alpha value generated by PLS is slightly underestimated, so it is recommended to use the composite reliability value [75]. 
Likewise, with the AVE value, the above variables have an AVE value above 0.50; therefore, it can be said that each variable has a high discriminant validity.

Internal consistency and reliability

\begin{tabular}{|c|c|c|c|c|}
\hline Construct & $\begin{array}{l}\text { Factor } \\
\text { loading }\end{array}$ & $\mathrm{Ca}$ & CR & AVE \\
\hline $\begin{array}{l}\text { Comfort1 } \\
\text { Comfort2 } \\
\text { Comfort3 } \\
\text { Comfort4 } \\
\text { Comfort5 }\end{array}$ & $\begin{array}{l}0.777 \\
0.805 \\
0.828 \\
0.820 \\
0.755 \\
\end{array}$ & 0.858 & 0.897 & 0.636 \\
\hline $\begin{array}{l}\text { Competence1 } \\
\text { Competence3 } \\
\text { Competence5 } \\
\text { Competence6 } \\
\text { Competence7 } \\
\text { Competence8 } \\
\text { Competence9 } \\
\end{array}$ & $\begin{array}{l}0.754 \\
0.772 \\
0.723 \\
0.884 \\
0.815 \\
0.904 \\
0.735 \\
\end{array}$ & 0.906 & 0.926 & 0.641 \\
\hline $\begin{array}{l}\text { Status1 } \\
\text { Status2 } \\
\text { Status3 } \\
\text { Status4 } \\
\text { Status5 } \\
\text { Status6 } \\
\text { Status7 } \\
\end{array}$ & $\begin{array}{l}0.860 \\
0.841 \\
0.833 \\
0.756 \\
0.703 \\
0.831 \\
0.806 \\
\end{array}$ & 0.910 & 0.928 & 0.649 \\
\hline $\begin{array}{l}\text { KnowledgeSharing1 } \\
\text { KnowledgeSharing2 } \\
\text { KnowledgeSharing3 } \\
\text { KnowledgeSharing4 }\end{array}$ & $\begin{array}{l}0.778 \\
0.840 \\
0.824 \\
0.888 \\
\end{array}$ & 0.854 & 0.901 & 0.649 \\
\hline $\begin{array}{l}\text { Creative1 } \\
\text { Creative2 } \\
\text { Creative3 } \\
\text { Creative4 }\end{array}$ & $\begin{array}{l}0.874 \\
0.847 \\
0.896 \\
0.784 \\
\end{array}$ & 0.873 & 0.913 & 0.725 \\
\hline
\end{tabular}

Source: Researchers Own Survey (2020).

Structural model. Testing the inner model or structural model is done to see the relationship between the construct, the significance value, and the $\mathrm{R}^{2}$ of the research model [76]. The structural model is evaluated using $\mathrm{R}^{2}$ for the dependent construct of the t-test as well as the significance of the coefficient of structural path parameters. Assessing a model with PLS starts by looking at the $\mathrm{R}^{2}$ for each latent dependent variable. Table 2 shows the results of $\mathrm{R}^{2}$ estimation using SmartPLS.

Table 2

\section{R-square results}

\begin{tabular}{|l|l|l|}
\hline Variable & $\mathbf{R}^{\mathbf{2}}$ & $\mathbf{R}^{\mathbf{2}}$ adjusted \\
\hline Creative Performance & 0.647 & 0.642 \\
\hline Knowledge Sharing & 0.768 & 0.766 \\
\hline
\end{tabular}

Source: Researchers Own Survey (2020). 
Table 2 shows the $\mathrm{R}^{2}$ value for the CP obtained at 0.647 and for the KS obtained at 0.768 . These results indicate that $64.7 \%$ of the $\mathrm{CP}$ can be influenced by $\mathrm{CF}, \mathrm{CPT}, \mathrm{ST}$, and KS; the rest are influenced by other variables not included in the study. However, $76.8 \%$ of KS is influenced by the CF, CPT, and ST; the rest is influenced by other variables not found in the study.

Furthermore, the total value of $\mathrm{R}^{2}$ (see Table 2 ) is used to predictive relevance $\left(\mathrm{Q}^{2}\right)$. The blinfolding approach measures the predictive relevance $\left(\mathrm{Q}^{2}\right)$ and the effect Q2 or impact of exogenous constructs on endogenous constructs (Henseler et al., 2009). As shown in Table 2, the value of $\mathrm{Q}^{2}$ in this study can be measured by the following calculation:

$$
\begin{aligned}
& \mathrm{Q}^{2}=1-\left(1-\mathrm{R} 1^{2}\right)\left(1-\mathrm{R} 2^{2}\right) \\
& \mathrm{Q}^{2}=1-(1-0.647)(1-0.768) \\
& \mathrm{Q}^{2}=0.918104
\end{aligned}
$$

The predictive value of relevance $\left(\mathrm{Q}^{2}\right)$ for the structural model in this study is 0.918 or $91.8 \%$, meaning that the model is able to explain the phenomenon of performance associated with several variables, namely, CF, CPT, ST, and KS. Therefore, the model can be said to be very good or the model has a very good predictive value. In the end, the model can be used for hypothesis testing.

Hypotheses testing. After knowing the questionnaire items' validity and reliability and knowing the resulting model from the SEM analysis and the feasibility of the model, we test the previously compiled hypotheses. This hypothesis testing is based on the significance value ( $p$-value) $<0.05$. If the significance value is less than 0.05 , there is an influence between variables and the accepted hypothesis. The results of hypothesis testing for direct effect can be seen in Table 3 below.

Table 3

\section{Direct effect}

\begin{tabular}{|l|l|l|l|l|}
\hline Hypothesis & Relationship & $\boldsymbol{\beta}$ & p values & Status \\
\hline H1 & CF $\rightarrow$ CP & 0.317 & 0.006 & Not significant \\
\hline H2 & CPT $\rightarrow$ CP & 0.195 & 0.153 & Not significant \\
\hline H3 & ST $\rightarrow$ CP & 0.125 & 0.238 & Not significant \\
\hline H4 & KS $\rightarrow$ CP & 0.223 & 0.005 & Significant \\
\hline
\end{tabular}

Source: Researchers Own Survey (2020).

In the indirect effect, Table 4 showed that two paths were significant. We run a contestant bootstrapping with 5,000 sub-samples to estimate the p-values to assess the level of significance for specific indirect effect as shown in Table 4.

Table 4

Indirect effect

\begin{tabular}{|l|l|l|l|l|}
\hline Hypothesis & Relationship & $\boldsymbol{\beta}$ & p values & Status \\
\hline H5a & CF $\rightarrow$ KS $\rightarrow$ CP & 0.045 & 0.029 & Significant \\
\hline H5b & CPT $\rightarrow$ KS $\rightarrow$ CP & 0.044 & 0.174 & Not significant \\
\hline H5c & ST $\rightarrow$ KS $\rightarrow$ CP & 0.114 & 0.028 & Significant \\
\hline
\end{tabular}

Source: Researchers Own Survey (2020). 


\section{Discussion and Conclusion}

First, this research has discovered new antecedent factor for creative performance. Previously, research discussing creative performance generation mechanism has primarily focused on employees behavior and organizational factors $[16 ; 3]$. This research has found the impact of work values towards creative performance through empirical study. Our findings show that employees work values, mainly comfort and status dimensions have insignificant impacts on creative performance if the mediation of knowledge sharing intention is not included. This research concludes that by the mediation of knowledge sharing intention, work values will affect creativity. Comfort has insignificant negative impacts on creative performance. Competence and status have insignificant effects on creative performance. In conclusion, this research has theoretical and significance values. This research will not only identify new factors affecting creative performance, but also promote further research conducted in other industrial areas. It will provide new perspective for future research and promote further research concerning the correlation between work values and creative performance.

Second, this research explores creative performance mechanism work values perspective. Through this research, we discover affecting line that has work values on creative performance. Specifically, comfort and status values indirectly affect creative performance. Their impact results from full mediation of knowledge sharing. In the other hand, competence value has neither indirectly affected creative performance, nor has indirect effects through the mediation of knowledge sharing. This research will not only enrich and develop the result of existing research, but also describe the affecting line of work values towards creative performance.

Briefly, this paper has discovered the correlation between work values and creative performance through empirical study and widened the field of work values research, and therefore will fill the discrepancy on the existing research. At the same time, this research also implements the specific effects of work values on creative performance with knowledge sharing mediation. The conclusion is promoting the creative theory development.

Moreover, these findings provide the important guide and have reference values for management practice. Creative performance is an important guarantee for a company to obtain competitive supremacy and have specific meaning for a company in competitive market environment competition. The correlation between work values and creative performance, and impact mechanism, provide such important management ideas for managers to effectively improve their employees' creative performance. These findings allow managers to notice the importance of work values for innovation performance. It will inspire managers to take the targeted steps in their work in order to improve creative performance level.

This paper proposes two suggestions for management practice. First, observe the employees' work values management. According to self-verification theory and the result of work values, we can discover that employees' intrinsic values will have important impacts on their manner and work behavior [50; 57; 55]. Accordingly, managers should observe more on the employees' work values management and establish a scientific evaluation and selection mechanism. Specifically, apply 
knowledge management and its implementation. Particularly for a position with higher creative requirement, managers should adopt scientific and effective values evaluation tools to select employees who pursue higher ability and growth, status, and independence. Second, build knowledge sharing mechanism in the company. The innovation theory and relevant research result show that sharing knowledge plays strong positive roles in promoting employees' innovation performance [59; 17; 31]. Manager should observe more on the development of knowledge sharing mechanism, overcome the traditional thought and mode, fully utilize modern tools to build knowledge sharing platform, extend the knowledge sharing channels, improve the convenience, and review the effectiveness of knowledge sharing.

This research has two major limitations. One of the limitations is external validity issues. The research data were only collected from 315 construction companies in Jakarta represented by company representatives as the sample. According to Slovin approach, it should obtain 324 respondents as sample, but only 315 respondents responded. Besides, another issue is that this research ignores the impact of organizational level factors. The work values could be affected by organizational factors, such as leadership or company culture. Thus, the future study should observe more on the effect of these factors on the correlation between work values and creative performance.

\section{REFERENCES}

[1] Liu Y., Wang S., Yao X. Individual Goal Orientations, Team Empowerment, and Employee Creative Performance: A Case of Cross-level Interactions. Journal of Creative Behavior. 2019; 53 (4): 443-456. DOI: 10.1002/jocb.220

[2] Martinaityte I., Sacramento C., Aryee S. Delighting the Customer: Creativity-Oriented High-Performance Work Systems, Frontline Employee Creative Performance, and Customer Satisfaction. Journal of Management. 2019; 45 (2): 728-751. DOI: 10.1177/ 0149206316672532

[3] Wallace J.C., Butts M.M., Johnson P.D., Stevens F.G., Smith M.B. A Multilevel Model of Employee Innovation: Understanding the Effects of Regulatory Focus, Thriving, and Employee Involvement Climate. Journal of Management. 2016; 42 (4): 982-1004. DOI: $10.1177 / 0149206313506462$

[4] Amabile T. A Model of Creativity and Innovation in Organizations. Research in Organizational Behavior. 1988; 10 (1): 123-167.

[5] Saad G., Cleveland M., Ho L. Individualism-collectivism and the Quantity Versus Quality Dimensions of Individual and Group Creative Performance. Journal of Business Research. 2015; 68 (3): 578-586.

[6] Aryanto R., Fontana A., Afiff A.Z. Strategic Human Resource Management, Innovation Capability and Performance: An Empirical Study in Indonesia Software Industry. ProcediaSocial and Behavioral Sciences. 2015; 211: 874-879. DOI: 10.1016/j.sbspro.2015.11.115

[7] Hendrayati H., Gaffar V. Innovation and Marketing Performance of Womenpreneur in Fashion Industry in Indonesia. Procedia - Social and Behavioral Sciences. 2016; 219: 299306. DOI: 10.1016/j.sbspro.2016.04.034

[8] Julison B., Wardani S.P.R., Wibowo M.A. Innovation Performance of Large Contractor in Indonesia: Influencing Factors and its Impact on Firm's Performance. Procedia Engineering. 2017; 171: 370-378. DOI: 10.1016/j.proeng.2017.01.346

[9] Elia S., Kafouros M., Buckley P.J. The Role of Internationalization in Enhancing the Innovation Performance of Chinese EMNEs: A geographic Relational Approach. Journal of International Management. 2020; 26 (4): 100801. DOI: 10.1016/j.intman.2020.100801 
[10] Hong J., Zheng R., Deng H., Zhou Y. Green Supply Chain Collaborative Innovation, Absorptive Capacity and Innovation Performance: Evidence from China. Journal of Cleaner Production. 2019; 241: 118377.

[11] Mutonyi B.R., Slåtten T., Lien G. Organizational Climate and Creative Performance in the Public Sector. European Business Review. 2020; 32 (4): 615-631. DOI: 10.1108/EBR-022019-0021

[12] Khalili A. Linking Leaders' Emotional Intelligence Competencies and Employees' Creative Performance and Innovative Behaviour: Evidence from Different Nations. International Journal of Innovation Management. 2016; 20 (7): 1650069. DOI: 10.1142/S1363919616500699

[13] Chen M.H., Chang Y.Y., Chang Y.C. Entrepreneurial Orientation, Social Networks, and Creative Performance: Middle Managers as Corporate Entrepreneurs. Creativity and Innovation Management. 2015; 24 (3): 493-507. DOI: 10.1111/caim.12108

[14] Choi J.N. Group Composition and Employee Creative Behaviour in a Korean Electronics Company: Distinct Effects of Relational Demography and Group Diversity. Journal of Occupational and Organizational Psychology. 2007; 80 (2): 213-234. DOI: 10.1348/096317906X110250

[15] Pieterse A.N., Knippenberg D.V., Schippers M., Stam D. Transformational and Transactional Leadership and Innovative Behavior: The Moderating Role of Psychological Empowerment. Journal of Organizational Behavior. 2010; 31 (4): 609-623. DOI: 10.1002/job.650

[16] Carmeli A., Gelbard R., Reiter-Palmon R. Leadership, Creative Problem-Solving Capacity, and Creative Performance: The Importance of Knowledge Sharing. Human Resource Management. 2013; 52 (1): 95-121. DOI: 10.1002/hrm

[17] Sharifirad M.S. Can Incivility Impair Team's Creative Performance Through Paralyzing Employee's Knowledge Sharing? A Multi-level Approach. Leadership and Organization Development Journal, 2016; 37 (2): 200-225. DOI: 10.1108/LODJ-05-2014-0092

[18] Isaksen S. G., Ekvall G. Managing for innovation: The Two Faces of Tension in Creative Climates. Creativity and Innovation Management. 2010; 19 (2): 73-88. DOI: 10.1111/ j.1467-8691.2010.00558.x

[19] Gilmore P.L., Hu X., Wei F., Tetrick L.E., Zaccaro S.J. Positive Affectivity Neutralizes Transformational Leadership's Influence on Creative Performance and Organizational Citizenship Behaviors. Journal of Marriage and Family. 2013; 34 (8): 1061-1075. DOI: $10.1002 /$ job.1833

[20] Griffith J.A., Gibson C., Medeiros K., MacDougall A., Hardy J., Mumford M.D. Are You Thinking What I'm Thinking?: The Influence of Leader Style, Distance, and Leader-Follower Mental Model Congruence on Creative Performance. Journal of Leadership and Organizational Studies. 2018; 25 (2): 153-170. DOI: 10.1177/1548051817750537

[21] Shin S.J., Zhou J. Transformational Leadership, Conservation, and Creativity: Evidence from Korea. Academy of Management Journal. 2003; 46 (6): 703-714. DOI: 10.5465/30040662

[22] Zhang X., Bartol K.M. The Influence of Creative Process Engagement on Employee Creative Performance and Overall Job Performance: A Curvilinear Assessment. Journal of Applied Psychology. 2010; 95 (5): 862-873. DOI: 10.1037/a0020173

[23] Malik M.A.R., Butt A.N., Choi J.N. Rewards and Employee Creative Performance: Moderating Effects of Creative Self-efficacy, Reward Importance, and Locus of Control. Journal of Organizational Behaviour. 2015; 36 (1): 59-74. DOI: 10.1002/job.1943

[24] Ng T.W.H., Feldman D.C., Lam S.S.K. Psychological Contract Breaches, Organizational Commitment, and Innovation-related Behaviors: A Latent Growth Modeling Approach. Journal of Applied Psychology. 2010; 95 (4): 744-751. DOI: 10.1037/a0018804

[25] Kirkman B.L., Shapiro D.L. The Impact of Cultural Values on Job Satisfaction and Organizational Commitment in Self-Managing Work Teams: The Mediating Role of Employee Resistance. Academy of Management, 2001; 44 (3): 557-569.

[26] Williams P., Kern M.L., Waters L. The Role and Reprocessing of Attitudes in Fostering Employee Work Happiness: An Intervention Study. Frontiers in Psychology. 2017; 8 (28): 1-12. DOI: 10.3389/fpsyg.2017.00028

[27] Elizur D., Sagie A. Facets of Personal Values: A Structural Analysis of Life and Work Values. Applied Psychology. 1999; 48 (1): 73-87. DOI: 10.1080/026999499377673

[28] Froese F.J., Xiao S. Work Values, Job Satisfaction, and Organizational Commitment in China. International Journal of Human Resource Management. 2012; 23 (10): 2144-2162. DOI: $10.1080 / 09585192.2011 .610342$ 
[29] Ueda Y., Ohzono Y. Effect of Work Values on Work Outcomes: Investigating Differences Between Job Categories. International Journal of Business Administration. 2012; 3 (2): 98111. DOI: 10.5430/ijba.v3n2p98

[30] Lee J.N. The Impact of Knowledge Sharing, Organizational Capability and Partnership Quality on IS Outsourcing Success. Information and Management. 2001; 38 (5): 323-335. DOI: $10.1016 / \mathrm{S} 0378-7206(00) 00074-4$

[31] Tong C., Tak W.I. W., Wong A. The Impact of Knowledge Sharing on the Relationship between Organizational Culture and Job Satisfaction: The Perception of Information Communication and Technology (ICT) Practitioners in Hong Kong. International Journal of Human Resource Studies. 2015; 5 (1): 19-47. DOI: 10.5296/ijhrs.v3i1.3112

[32] Charband Y., Navimipour N.J. Knowledge Sharing Mechanisms in the Education: A Systematic Review of the State of the Art Literature and Recommendations for Future Research. Kybernetes. 2018; 47 (7): 1456-1490. DOI:10.1108/K-06-2017-0227

[33] Ma Z., Long L., Zhang Y., Zhang J., Lam C.K. Why Do High-performance Human Resource Practices Matter for Team Creativity? The Mediating Role of Collective Efficacy and Knowledge Sharing. Asia Pacific Journal of Management. 2017; 34 (3): 565-586. DOI: $10.1007 / \mathrm{s} 10490-017-9508-1$

[34] Navimipour N.J., Navin A.H., Rahmani A.M., Hosseinzadeh M. Behavioral Modeling and Automated Verification of a Cloud-based Framework to Share the Knowledge and Skills of Human Resources. Computers in Industry. 2015; 68: 65-77. DOI: 10.1016/ j.compind.2014.12.007

[35] Navimipour N.J., Rahmani A.M., Navin A.H., Hosseinzadeh M. Expert Cloud: A Cloudbased Framework to share the Knowledge and Skills of Human Resources. Computers in Human Behavior. 2015; 46: 57-74. DOI: 10.1016/j.chb.2015.01.001

[36] Zareie B., Navimipour N.J. The Impact of Electronic Environmental Knowledge on the Environmental Behaviors of People. Computers in Human Behavior. 2016; 59: 1-8. DOI: 10.1016/j.chb.2016.01.025

[37] Fouladi P., Navimipour N.J. Human Resources Ranking in a Cloud-based Knowledge Sharing Framework Using the Quality Control Criteria. Kybernetes, 2017; 46 (5): 876-892. DOI: $10.1108 / \mathrm{K}-01-2017-0007$

[38] Navimipour N.J., Charband Y. Knowledge Sharing Mechanisms and Techniques in Project Teams: Literature Review, Classification, and Current Trends. Computers in Human Behavior. 2016; 62: 730-742. DOI: 10.1016/j.chb.2016.05.003

[39] Woodfield P., Husted K. Intergenerational Knowledge Sharing in Family Firms: Casebased Evidence from the New Zealand Wine Industry. Journal of Family Business Strategy. 2017; 8 (1): 57-69. DOI: 10.1016/j.jfbs.2017.01.001

[40] Charband Y., Jafari Navimipour N. Online Knowledge Sharing Mechanisms: A Systematic Review of the State of the Art Literature and Recommendations for Future Research. Information Systems Frontiers. 2016; 18 (6): 1131-1151. DOI: 10.1007/s10796-016-9628-z

[41] Schmitz M.A. Change in China? Taking Stock of Blue Collars' Work Values. Journal of Chinese Human Resource Management. 2019; 10 (1-2): 49-68. DOI: 10.1108/JCHRM-082018-0014

[42] Cherrington D. The Values of Younger Workers. Business Horizons. 1977; 20 (6): 18-30. DOI: 10.1016/0007-6813(77)90021-0

[43] Ralston D.A., Egri C.P., Karam C.M., Li Y., Fu P.P. Changes in Work Values Across the Regions of China. Asia Pacific Journal of Management. 2018; 35 (1): 145-179. DOI: 10.1007/s10490-017-9519-y

[44] Twenge J.M., Campbell S.M., Hoffman B.J., Lance C.E. Generational Differences in Work Values: Leisure and Extrinsic Values Increasing, Social and Intrinsic Values Decreasing. Journal of Management. 2010; 36 (5): 1117-1142. DOI: 10.1177/0149206309352246

[45] Yang J., Yu C.S., Wu J. Work Values across Generations in China. Chinese Management Studies. 2018; 12 (3): 486-505. DOI: 10.1108/CMS-12-2017-0357

[46] Cherrington D.J., Condie S.J., England J.L. Age and Work Values. The Academy of Management Journal. 1979; 22 (3): 617-623. DOI: 10.2307/255750

[47] Lechner C.M., Sortheix F.M., Göllner R., Salmela-Aro K. The Development of Work Values during the Transition to Adulthood: A Two-country Study. Journal of Vocational Behavior, 2017; 99: 52-65. DOI: 10.1016/j.jvb.2016.12.004 
[48] Lindsay P., Knox W.E. Continuity and Change in Work Values Among Young Adults: A Longitudinal Study. American Journal of Sociology. 1984; 89 (4): 918-931.

[49] Furnham A., Petrides K.V., Tsaousis I., Pappas K., Garrod D. A Cross-cultural Investigation into the Relationships between Personality Traits and Work Values. Journal of Psychology: Interdisciplinary and Applied. 2005; 139 (1): 5-32. DOI: 10.3200/JRLP.139.1.5-32

[50] Blickle G., Fröhlich J.K., Ehlert S., Pirner K., Dietl E., Hanes T.J., Ferris G.R. Socioanalytic theory and work behavior: Roles of Work Values and Political Skill in Job Performance and Promotability Assessment. Journal of Vocational Behavior. 2011; 78 (1): 136-148. DOI: $10.1016 /$ j.jvb.2010.05.010

[51] Hegney D., Plank A., Parker V. Extrinsic and Intrinsic Work Values: Their Impact on Job Satisfaction in Nursing. Journal of Nursing Management. 2006; 14 (4): 271-281. DOI: 10.1111/j.1365-2934.2006.00618.x

[52] Hsu Y. Work Values, Conflict, and Team Cooperation Among Engineering Designers. Journal of Engineering Design. 2017; 28 (10-12): 799-820. DOI: 10.1080/09544828.2017.1397268

[53] Moorman R.H., Blakely G.L. Individualism-collectivism as an Individual Difference Predictor of Organizational Citizenship Behavior. Journal of Organizational Behavior. 1995; 16 (2): 127-142. DOI: $10.1002 /$ job.4030160204

[54] Meyer J.P., Irving P.G., Allen N.J. Examination of the Combined Effects of Work Values and Early Work Experiences on Organizational Commitment. Journal of Organizational Behavior. 1998; 19 (1): 29-52.

[55] Swann W.B. To Be Adored or to Be Known? The Interplay of Self-enhancement and SelfVerification. Motivation and Cognition. 1990: 408-448.

[56] Ryan J.J. Work Values and Organizational Citizenship Behaviors: Values that Work for Employees and Organizations. Journal of Business and Psychology. 2002; 17 (1): 123-132. DOI: $10.1023 / \mathrm{A}: 1016246103190$

[57] Jalalkamali M., Ali A.J., Hyun S.S., Nikbin D. Relationships Between Work Values, Communication Satisfaction, and Employee Job Performance: The Case of international Joint Ventures in Iran. Management Decision. 2016; 54 (4): 796-814. DOI: 10.1108/MD-01-2015-0003

[58] Shapira Z., Griffith T.L. Comparing the Work Values of Engineers with Managers, Production, and Clerical Workers: A Multivariate Analysis. Journal of Organizational Behavior. 1990; 11 (4): 281-292. DOI: 10.1002/job.4030110404

[59] Hong P., Doll W.J., Nahm A.Y., Li, X. Knowledge Sharing in Integrated Product Development. European Journal of Innovation Management. 2004; 7(2): 102-112. DOI: 10.1108/ 14601060410534393

[60] Liao S.H., Fei W.C., Chen C.C. Knowledge Sharing, Absorptive Capacity, and Innovation Capability: An Empirical Study of Taiwan's Knowledge-intensive Industries. Journal of Information Science. 2007; 33 (3): 340-359. DOI: 10.1177/0165551506070739

[61] Kimble C., Grenier C., Goglio-Primard K. Innovation and Knowledge Sharing Across Professional Boundaries: Political Interplay Between Boundary Objects and Brokers. International Journal of Information Management. 2010; 30 (5): 437-444. DOI: 10.1016/j.jinfomgt.2010.02.002

[62] Johnson L.D., Neave E.H., Pazderka B. Knowledge, Innovation, and Share Value. International Journal of Management Reviews. 2002; 4 (2): 101-134. DOI: 10.1111/14682370.00080

[63] Zhang Y., Sun J.M., Lin C.H., Ren H. Correction to: Linking Core Self-Evaluation to Creativity: The Roles of Knowledge Sharing and Work Meaningfulness. Journal of Business and Psychology. 2020; 35 (2), 271-272. DOI: 10.1007/s10869-018-09614-7

[64] Rivera-Vazquez J.C., Ortiz-Fournier L.V., Flores F.R. Overcoming Cultural Barriers for Innovation and Knowledge Sharing. Journal of Knowledge Management. 2009: 13 (5): 257-270. DOI: 10.1108/13673270910988097

[65] McKaughan D.J. On the Value of Faith and Faithfulness. International Journal for Philosophy of Religion. 2017; 81 (1-2): 7-29. DOI: 10.1007/s11153-016-9606-x

[66] Meglino B.M., Ravlin E.C. Individual Values in Organizations: Concepts, controversies, and Research. Journal of Management. 1998; 24 (3): 351-389. DOI: 10.1177/ 014920639802400304 
[67] Toode K., Routasalo P., Suominen T. Work Motivation of Nurses: A Literature Review. International Journal of Nursing Studies. 2011; 48 (2): 246-257. DOI: 10.1016/ j.ijnurstu.2010.09.013

[68] Tejada J., Punzalan J. On the Misuse of Slovin's Formula. The Philippine Statistician. 2012; 61 (1): 129-136.

[69] Pi S.M., Chou C.H., Liao H.L. A Study of Facebook Groups Members' Knowledge Sharing. Computers in Human Behavior. 2013; 29 (5): 1971-1979. DOI: 10.1016/j.chb.2013.04.019

[70] Welbourne T.M., Johnson D.E., Erez A. The Role-based Performance Scale: Validity Analysis of a Theory-based Measure. Academy of Management Journal. 1998; 41 (5): 540555. DOI: $10.2307 / 256941$

[71] Song J., Wu J., Gu J. Voice Behavior and Creative Performance Moderated by Stressors. Journal of Managerial Psychology. 2017; 32 (2):177-192. DOI: 10.1108/JMP-03-20160078

[72] Cepeda-Carrion G., Cegarra-Navarro J.G., Cillo V. Tips to Use Partial Least Squares Structural Equation Modelling (PLS-SEM) in Knowledge Management. Journal of Knowledge Management, 2019; 23 (1): 67-89. DOI: 10.1108/JKM-05-2018-0322

[73] Hair J.F., Sarstedt. M., Hopkins L., Kuppelwieser V.G. Partial Least Squares Structural Equation Modeling (PLS-SEM): An Emerging Tool in Business Research. European Business Review. 2014; 26 (2): 106-121. DOI: 10.1108/EBR-10-2013-0128

[74] Fornell C., Larcker D.F. Structural Equation Models with Unobservable Variables and Measurement Error: Algebra and Statistics. Journal of Marketing Research. 1981; 18 (3): 382. DOI: $10.2307 / 3150980$

[75] Peterson R.A., Kim Y. On the Relationship between Coefficient Alpha and Composite Reliability. Journal of Applied Psychology. 2013; 98 (1): 194-198. DOI: 10.1037/a0030767

[76] Hair J.F., Sarstedt M., Ringle C.M. Rethinking Some of the Rethinking of Partial Least Squares. European Journal of Marketing. 2019; 53 (4): 566-584. DOI: 10.1108/EJM-102018-0665

Information about the author:

Bimmo Dwi Baskoro - Master of Management, PhD Student of Sekolah Tinggi Manajemen Labora (Indonesia) (ORCID ID: 0000-0002-1209-0483) (e-mail: bimmodibi@gmail.com).

\title{
Ценность труда, обмен знаниями и творческая деятельность среди строительных рабочих в Джакарте
}

\author{
Б.Д. Баскоро \\ Школа менеджмента Секола Тингги, \\ 13910, Индонезия, Джакарта, Таман Модерн, Jl. Палем Раджа, № 7-8 \\ bimmodibi@gmail.com
}

Аннотация. В данном исследовании рассматривается влияние ценности труда строительных работников на творческую деятельность и оценивается роль посредничества в обмене знаниями между этими переменными. В представленном исследовании участвовали 315 респондентов из различных строительных компаний Джакарты. Система обмена знаниями играет роль посредника между измерениями комфорта и статуса - от ценности труда до творческих достижений. В исследовании предоставляется информация о влиянии ценности труда на творческую деятельность в строительной отрасли, подтверждающая роль обмена знаниями в рамках измерения ценности труда.

Ключевые слова: ценность труда, творческая деятельность, обмен знаниями

Заявление о конфликте интересов: Автор заявляет об отсутствии конфликта интересов. 
Благодарности. Автор благодарит Школу менеджмента Секола Тингги, DKI Джакарта, Индонезия, за поддержку этого исследования.

\section{История статьи:}

Статья поступила в редакцию: 20.01.2021. Статья принята к публикации:18.02.2021.

\section{Для цитирования:}

Baskoro B.D. Work Value, Knowledge Sharing, and Creative Performance among Construction Employees in Jakarta // Вестник Российского университета дружбы народов. Серия: Государственное и муниципальное управление. 2021. Т. 8. № 2. С. 200-215. DOI: 10.22363/2312-83132021-8-2-200-215

\section{Информация об авторе:}

Биммо Дви Баскоро - магистр менеджмента, аспирант школы менеджмента Секола Тингги (Индонезия) (ORCID ID: 0000-0002-1209-0483) (e-mail: bimmodibi@gmail.com). 